\title{
KARACAOĞLAN'DA GÖÇ
}

\section{MIGRATION IN KARACAOĞLAN'S POEMS}

\author{
МИГРАЦИЯ ПО РОМАНУ КАРАДЖАОГЛАН
}

\section{Bülent ARI ${ }^{*}$ - Hüseyin Kürşat TÜRKAN**}

\section{ÖZ}

17.yüzyıl Âşık Edebiyatı'nın en önemli temsilcilerinden biri olan Karacaoğlan, Güney Anadolu ve Toros yaylarının konar-göçer kültürünün de önemli bir bilgi kaynağıdır. Karacaoğlan yaşadığı coğrafyaya ve bu coğrafyanın kültürüne gönül bağıyla bağlıdır. Bu yüzden de mensubu olduğu konar-göçer kültür yapısı ona, gâh İç Anadolu'ya gâh Güney Doğu Anadolu'ya; Frrat vadisine, Suriye'ye; Hama, Hums'a Halep'e giderek gezdiği yerlerin kültür birikimini birinden diğerine taşıma olanağını vermiştir.

Karacaoğlan'ın şiirlerine göz gezdirdiğimizde, onun mensubu olduğu konar-göçer yaşam tarzının, göçebe bir âşık olarak gezip gördüğü coğrafyanın, içinde yetiştiği toplum yapısının, insanların birbirleriyle olan ilişkilerinin, özetle maddi manevi tüm unsurların ziyadesiyle yer aldığı görülebilir.

Kısacası Karacaoğlan'ın yukarıda sözünü ettiğimiz konar-göçer kültür yapısı içinde yer alması ve gezici âşıklık geleneğinin gerektirdiği durumdan dolayı şiirlerinin azımsanmayacak bir kısmında göç temasıyla karşılaşılmaktadır. Bizim bu makaledeki amacımız, bu şiirlerde öncelikle geçen göç ile ilgili kelime kadrosunu, sonrasında ise Karacaoğlan'ın şiirlerinde göç temasının yer aldığı şiirleri tespit ederek Karacaoğlan'ın şiirinde göç kavramıyla ifade ettiği şeyi ortaya çıkarmaya çalışmaktır.

Anahtar Kelimeler: Karacaoğlan, Göç, Konar-Göçerlik, Karacaoğlan Şiirinde Göç

\section{ABSTRACT}

Karacaoğlan, who is one of the most important representatives of $17^{\text {th }}$ century minstrelsy, is an important information source of nomadic culture of southern Anatolia and Taurus highlands. Karacaoğlan was bound up with the geography where he lived and culture of this geography. That is why this nomadic cultural structure gave him opportunity to convey cultural background of the places he visited including Central Anatolia, Southeastern Anatolia, Euphrates Valley, Syria, Hama, Humus and Aleppo.

When the poems of Karacaoğlan are skimmed, it can be seen that nomadic life style of which he was a member, the places he visited as a nomadic minstrel, social structure in which he grew up, relationship among people, shortly all material and nonmaterial elements were included.

In brief, as Karacaoğlan was in a nomadic cultural structure we mentioned above and because of mobile minstrelsy tradition, theme of migration can be seen in a considerable amount of his poems. Our aim in this article is to determine the words about migration in

* Doč. Dr., Mustafa Kemal Üniversitesi, Eğitim Fakültesi Türkçe Eğitimi Bölümü,bulentari01@gmail.com
* Yrd. Doç. Dr., Mustafa Kemal Universitesi, Fen-Edebiyat Fakültesi TDE Bölümü, khturkan@gmail.com

DOI: $10.17498 / \mathrm{kdeniz.377402}$ 
this poems, and then to reveal what Karacaoğlan meant by the notion of migration in his poems by classifying his poems in which theme of migration was studied according to their topics.

Keywords: Karacaoğlan, Migration, Nomadic Life, Migration in Karacaoğlan's Poems

\section{АННОТАЦИЯ}

Караджаоглан, один из лучших литературных произведений ашугской культуры 17-го века. Этот роман также является важным источником информации о культуре кочевников в Южной Анатолии и района Торос. Караджаоглан от всей души связан к месту своего проживания и его культурой. В связи с этим, структура и культура кочевого образа жизни даёт ему возможность распростронять свои ценности от центральной до юго-восточной Анатолии, в долинах Евфрата, в Сирия, Хаме, Хамсу и Алеппо.

В стихах Караджаоглана описывается структура его общества, отношения людей, материальные и духовные ценности этой местности и любовь к кочевому образу жизни.

В некоторых стихотворениях Караджаоглана, исходя из кочевого образа жизни и традиции путешественника, выдвигается проблема иммиграции.Цель этой статьи, установить в поэме стихотворения самого Караджаоглан и тему миграции в них.

Ключевые слова: Караджаоглан, миграция, кочевничество, миграция в тихотоворениях караджаоглан.

\section{Giriş}

\section{“Göç tek yönlü bir yolculuktur. Geri dönülecek bir 'yuva' yoktur.”}

(Stuart Hall)

Karacaoğlan mahlasını kullanan âşıkların geniş bir coğrafyada ve farklı yüzyıllarda yaşamış oldukları bilinmektedir (Durbilmez, 2007: 42). Bu makalede bahsi geçen âşık Çukurovalı Karacaoğlan'dır. Âşık tarzı şiirin en önemli temsilcilerinden biri sayılan bu Karacaoğlan'ın hayatı hakkındaki bilgilerimiz yok denecek kadar azdır. Onunla ilgili bildiklerimiz şiirlerinden hareketle öğrendiklerimiz, Karacaoğlan adına bağlı halk arasında yaşamakta olan hikâyeler, bir kısım menkıbeler ve tarihi kaynaklarda onunla ilişskilendirilebilecek birtakım değerlendirmelerden ibarettir (Sakaoğlu 2004: 105). Âşık Edebiyatı denilince akla ilk gelen isimlerin başında Karacaoğlan gelmektedir. Bunda onun Şiirlerini halk diliyle söylemesinin ve aşk, doğa, gurbet gibi konuları insana ve yaşama dönük, gerçekçi bir anlayışla dile getirmesinin önemli bir rolü vardır (Arı 2006: 94). Karacaoğlan, yaşadığı dönemin ve çevrenin sosyal-kültürel hayatını ve dilini çok iyi yansıtmış, içli ve duygulu şiirler söylemiş bir halk ozanıdır. Bu özelliklerinden dolayı da şiirleri günümüze kadar ulaşmış ve etkisini sürdürmeye devam etmiştir. Göç ve gurbet, Karacaoğlan şiirinin en önemli temlerindendir. Sıladan ve sevgiliden ayrılış, bilinmeyen yerlere ve bu dünyadan göç, Karacaoğlan'ın şiirlerinde sıklıkla geçmektedir. Onun şiirlerinde göç; gurbet, hasret, ayrılık, ölüm gibi temalarla birlikte yer almış; genellikle istenilmeyen ve arzulanmayan bir yer olarak görülmüştür. 


\section{Göç Kavramı}

Göç kavramının birçok tanımı yapılmıştır. Bu nedenle; kavramın ilk olarak sözlük tanımını verip daha sonra literatürdeki bazı tanımlara yer vermek faydalı olacaktır:

Türk Dil Kurumunun güncel Türkçe sözlüğünde (TDK, 2011: 954) göç kavramı "ekonomik, toplumsal, siyasi sebeplerle bireylerin veya toplulukların bir ülkeden başka bir ülkeye, bir yerleşim yerinden başka bir yerleşim yerine gitme işi, taşınma" olarak ifade edilmektedir. Göç, yerleşmek amacıyla bir yerleşim yerinden, başka bir yerleşim yerine doğru gerçekleşen mekân değiştirme eylemidir (Keleş, 1998; 25). Ancak bu tanımlama göçün daha çok demografik sürecine vurgu yapmakta, göçün içeriğini anlatmak bakımından sınırlı kalmaktadır. Bu açıdan göç, mekânsal bir yer değiştirme hareketinin yanı sıra, sosyal formasyonların ekonomik, politik ve kültürel yapıların ve bu yapılar içindeki ilişkiler sisteminde yaşanan değişimlerin sonucunda ortaya çıkan, söz konusu yapılar üzerinde de önemli değişim ve dönüşümlere yol açan bir olgudur (Özer, 2004: 11; Kaygalak, 2009: 9).

Temelleri insanlık tarihi kadar eski olan göç olgusu; bireyleri, bireylerin bir araya gelerek oluşturdukları toplumları, toplumların oluşturduğu devletleri ve onun iç-dış politikasını nihayetinde devletlerin ve örgütlerin bir araya gelerek oluşturduğu uluslararası sistemi ve uluslararası politikayı, ekonomik, siyasi, kültürel, psikolojik, sosyolojik vb. unsurlarla etkiler, yön verir, devşirir ya da değişime uğratır. Geniş kapsam ve boyutlara sahip olan göç olgusunu anlamak ve yorumlamak için onu oluşturan temel kavramları iyi çözümlemek gerekmektedir. En genel haliyle göçü; "ekonomik, toplumsal, siyasi sebeplerle bireylerin veya toplulukların bir ülkeden başka bir ülkeye, bir yerleşim yerinden başka bir yerleşim yerine gitme eylemi" olarak tanımlayabiliriz. (Dural ve Zeyrekli, 2006,1-2) Bu eylemi gerçekleştiren kişi ya da topluluklara ise "göçmen" denilmektedir. Tarih boyunca birçok neden, insanoğlunu göçe sürüklemiştir. Yeryüzünde her yıl milyonlarca insan, ekonomik, sosyal, güvenlik, sağlık, doğal afetler veya daha iyi yaşam koşullarına ulaşmak gibi birçok nedenle göç etmiştir. Tarih boyunca yaşanan göçler, toplumsal düzleme eşitsiz bir şekilde dağıtılmış olanaklardan yararlanma isteğinin bir sonucu olabildiği gibi çevreyle ilgili dayatmalar, otoritenin gündeme getirdiği sürgünler, mecburi iskânlar ve savaşlar nedeniyle ortaya çıkabilmektedir. Günümüzde göçe kaynaklık eden nedenler arasında, yoksulluk, işsizlik, siyasal koşullar, askeri çatışmalar, tarıma teknolojik aletlerin girmesi, hızlı nüfus artışı, yaşam biçiminin sınırlılığı, sosyal ve kültürel imkânlardan yararlanma isteği, gidilecek yerin iş yönünden çekiciliği, haberleşme ve ulaşım olanaklarındaki gelişmeler olarak sıralanmaktadır (Kocaman, 1993; 58).

Türk dili ve kültüründe "göç" sözcüğü çok değişik anlamlarda kullanılmaktadır. Halk arasında en basit ve yaygın kullanımı, bir barınma yerinden/mekânından başka bir yere gitmek, taşınmaktır. Geleneksel kültürümüzde insan ve toplum yaşamı ve üretim biçimiyle ilgili çok farklı boyutlarda "göç ve konmak" eylemlerinden türetilmiş yeni sözcük ve kavramların yaygınlaştığını görmekteyiz. Bu kullanım alanlarından biri de yaşam biçimleri, ekonomileri hayvancılığa dayanan göçer, yarı göçer yaylacı topluluklarda görülür. Öte yandan, köyden kente göçenlerin barınma sorunlarının çözümünde kullandıkları ve "konmak/yerleşmek" eyleminden türetilen kondu, gecekondu, konuk, konak vb. çok sayıda kavram dilimizde ve toplumsal yaşamımızda yer almıştır. Göç sözcüğünün, bu kullanımlarının dışında birey ve toplum yaşamını çok yakından ilgilendiren ve ekonomik, politik, ekolojik, sosyo-kültürel nedenlerden kaynaklanan çok sayıda kavramsal anlamı, olgusal düzeyi ve etkileri vardır. Bundan dolayı göç olayı ve olgusu, çeşitli bilim dallarınca farklı biçimlerde tanımlanıp açıklanmaktadır. Hangi boyutta ve hangi bilimsel yaklaşımla 
tanımlanırsa tanımlansın, göç, iki mekân arasındaki yer değiştirme, sosyal hareketlilik ve toplumsal değişme sürecidir.

\section{Halk Kültüründe Göc Kavramı}

Her göçün arkasında bıraktığı yangın yeri bir gönül ve virane bir yerdir. Göçten sonra mutlu bir gönül ve mamur bir yer görülmemiştir. Bu itibarla, göç veya göçlerle ilgili anlatıların hemen tamamı hüzünlüdür. Her göç anlatısı, biraz da bir şeyleri, bir yerleri kaybetmenin hikâyesidir. Bu yüzden göç, geçmişten günümüze biraz da bizim hikâyemizdir. Şüphesiz ki her toplumda çeşitli sebeplere bağlı olarak birçok göç yaşanmıştır. Ancak bu olguyu bizim kadar topyekûn, bizim kadar sürekli ve bizim kadar trajik yaşayan ikinci bir millet yok gibidir. Öyle ki destan devri yaşadığımız dönemlerden başlayarak günümüze gelinceye kadar göçmediğimiz bir dönem kalmamıştır. Bu duruma bağlı olarak göç hikâyelerimiz destanlarımızla beraber başlar (Ögel, 1998: 77-78; 81-82). "Göç" ve "göçmenlik" Türk kültürünün önemli belirleyenlerinden birini oluşturur. Kültürümüzdeki kavramlara baktığımızda, göçebeliğe ilişkin birçok yaşanmışlık ve kazanımın göç eksenine dayandığını görürüz. Hatta ölümü bile biz "Hakk'a yürüdü”, "göç etti" olarak nitelendiririz. Kültür hayatında, göçün bu denli belirleyici olduğu bir halkın, yaratmış olduğu edebiyat eserlerinde de bunun izlerini görmek kaçınılmazdır. Türk Halk Edebiyatında göç ve göçmenlik kavramları, destan döneminden başlayarak tarihsel bir olgu olarak da karşımıza çıkmaktadır. Destan döneminden, günümüze uzanan çizgide göçün, kültür ve edebiyat dünyamızda geniş bir yer kapladığı ortadadır.

Destanların içinden çıktıkları millet ve toplumların sosyo-kültürel hayatı açısından önemlerini dikkate alacak olursak tarih sahnesine çıkışımızdan itibaren göçün hayatımızın bir parçası olduğunu görürüz. Ergenekon, Şu, Türeyiş gibi destanlarımızda da göç olayına tanık oluruz. Var olmak ya da yok olmak arasında yaşayan bir topluluk, kendini korumak için ister istemez, sürekli göç etmek zorunda kalmıştır.

Göç, destanlarımız veya sözlü geleneğimiz yanında, daha ilk dönemdeki yazılı eserlerimize de konu olmuştur. Doğal olarak yaşananlar hiç de iç açıcı değildir. Kültigin gereksiz yapılan ve sonu çok acı biten bir göç eylemini "Mukaddes Ötüken ormanının milleti gittin, doğuya giden gittin. Batıya giden gittin. Gittiğin yerde hayrın herhalde şu oldu: Kanın su gibi koştu, kemiğin dăg gibi yattı. Beylik erkek evladın kul, hanımlık kız evladın cariye oldu. Bilmediğin için kötülüğ̈̈n yüzünden amcan, kağan uçup gitti." (Ergin 1991: 24) diyerek çok sert biçimde tenkit etmiştir.

Öte yandan Türklerde hem yazlık hem de kışlık oturma yerlerinin ayrı ayrı değerleri vardır. Bunlardan biri diğerini tamamlardı. Kışlık ve yazlık ev, her çağda ve her bölgede henüz önemini kaybetmemiştir. Ayrıca modern hayata girildikçe böyle bir yaşama isteği, gittikçe de baskısını artırmaktadır. Türkler göç sözünü daha çok, kendi evine yakın olan bölgelere gidiş ve geliş için kullanırdı. Büyük göçler, uzak bölgelerde yeni yurtlar aramak ve yurt edinmek manasına gelirdi ki, bu da çoğu zaman devlet eli ile hiç olmazsa devletin ve ordunun himayesinde olurdu. Aslında yaylak ve kışlak hayatı da göçer hayat ile yerleşik hayat arasında duran bir hayat tarzıdır. At üzerinde zamanı hızlı akıtmaya çalışan ve bir mekâna bağlı olmaktansa göçerek ve dolayısıyla gezerek yaşamayı tercih eden bir anlayış, Anadolu'da kendini yakın zamanlara kadar Yörüklerde göstermiştir.

Göçün ardında arzulanan, özlenen bir sıla vardır. Sıla, annenin, babanın, eşinin, çocuklarının, dostlarının ve sevdiğinin bulunduğu yerdir. Âşıkta hep orası ile ilgili düşünceler vardır. Sıla ile bağlantısını hiç kesmek istemez. Oradan haber, selam bekler. Aynı şekilde oraya haber, selam ve özlemlerini yollar. Sıla ile âşığın bağlantısını, bazen kuşlar bazen bir seher yeli ve kimi zaman bir mektup sağlar. Göç eden âşığa sıladan selam 
ve haber getirirler. Âşıkla dertleşip ona sırdaş olurlar. Göç ederek gurbeti içinde duyan âşı̆̆ korkutan en önemli şey, yabancı yerlerde ölümü yaşamaktır. Siladan uzak yerlerde ölmek, âşıkların en büyük endişe ve korkularındandır. Göç eden âşıklar, yaşadığı yerlerdeki sıkıntıları feleğe şikâyet ederek dile getirirler. Bu durumdan feleği sorumlu tutarak feleğe sitem ederler. Fakat sonunda yine de boyun eğip kaderlerine rıza gösterirler. Göçün bir sonucu olarak yaşadığı gurbette âşık, sılasının güzelliklerini hatırlar; acısına, yalnızlığına bir avunma aracı olarak görür. Şarkı ve türkülerimizde olduğu kadar halk şiirimizde de daha fazlasıyla konu olan "göç" olgusu günümüzde de hayatımızın bir parçası olarak kalacaktır. Kaçınılmaz bir gerçek olan göç, dünya var oldukça insanımızın bir sorunu olarak yerini koruyacaktır.

"Yaylaya göç" ve "yayla kültürü" ise âşık şiirinin en önemli temlerindendir. Sıladan ayrılış ve bilinmeyen yerlere göç, ne kadar umutsuz ve acılı olsa da; yaylaya göçte umut, heyecan, bir duygu coşkunluğu vardır. Âşık, sevgiliyi bulma, onunla görüşme ve bazı güzel anları yaşamak için yaylaya göç etmek ister. Anadolu insanı, yazları soğuk ve serin suları, temiz havası ve sessiz bir hayat için yaylaya gitme özlemi içindedir. İnsan hayatına ve sağlığına olumlu katkılarından dolayı yaylada kalmak ve yaşamak arzu edilen durumdur. İnsanın ebedi hayata göçüşü, dünyayı terk edişi de bazı âşıklarımızı ilgilendirmiş ve bu, onların şiirlerinin esas dokusu olmuştur. Ayrıca deprem, sel, yangın gibi birtakım büyük felaketler ve bir gencin dünyadan göçüşü gibi olaylar karşısında âşıklar susmamış, sözün gücünü şiirleriyle ortaya koymuşlardır.

Türk halk şiirinin büyük temsilcilerinden biri olan Karacaoğlan'a göre dünya bir yalandır. Bir gün gelip insanın bu yalancı dünyadan ebedi dünyaya göç edeceği düşüncesindedir. Kafesteki can kuşu uçacak ve dünya tarumar olacaktır. Öldükten sonra annesinin başını kucağına alıp ağlamasını ve yastığının kara toprak olduğunu belirtir. Dünyadan ahirete giden yolda başına çok işler gelecek ve mezar taşında da baykuşlar ötecektir:

Yürü bire yalan dünya

Sana konan göçer bir gün

Insan bir ekin misali

Seni eken biçer bir gün

Ăgalar içmesi hoştur

$O$ da züğürtlere güçtür

Can kafeste duran kuştur

Elbet uçar gider bir gün

Yerimi serin bucă̆a

Suyumu koyun ocă̆a

Kafamı alın kucăga

Garip anam ağlar bir gün

Yer üstünde yeşil yaprak

Yer altında kefen yırtmak

Yastığımız kara toprak

$O$ da bizi atar bir gün 
Bindirirler cansiz ata

Indirirler tuta tuta

Var dünyadan yol ahrete

Yelgin gider salın bir gün

Karac'oğlan der nâş̧ıma

Çok işler geldi başıma

Mezarımın baș taşına

Baykuş konar öter bir gün (Çelik, 2008: 138).

Anadolu insanının kader çıkmazlarından biri de göçtür. Ekmek parası, daha iyi geçim şartları ve rahat bir hayata kavuşmak düşüncesiyle; insanlar vatanlarını bırakıp büyük şehirlere yerleşmişlerdir. Geride bıraktıkları yerlerdeki köyler ve beldeler de 1ssız bir yurda ve harabeye dönmüştür. Halk şairlerimiz de bu sılayı terk edişin iç sızılarını şiirlerinde yansıtmış ve duyurmaya çalışmışlardır.

Göç bir yerden bir yere doğru gitmeyi ifade ederken, onun yanında gurbet ayrılıközlem vb. duyguları da beraberinde yaşatmaktadır. Halk arasında duygu yoğunluğu yaşanmakta ve her yörede kendine uygun folklorik yapıları ile göç konusu, türkü olarak karşımıza çıkmaktadır. Bu türkülerin bir kısmı "uzun hava", bir kısmı "kırık hava", bir kısmı da "atma türküler" olarak karşımıza çıkmaktadır.

\section{Karacaoğlan'ın Şiirlerinde Göc}

Çıktım seyreyledim Niğde'yi Bor'u Acep gezsem mavi donlum var m'ola Güzeller durağı Tokat Engürü Aceb gezsem mavi donlum var m'ola Hey geri de deli gönlüm hey geri Adana Elbeğli Göğsün Tekir'i

Otuz iki sancak Diyarbekir' $i$

Aceb gezsem mavi donlum var m'ola

Haşiri de deli gönül haşiri

Deryada dönüyor kıral yesiri

Haleb Tirabulus koca Misir'

Aceb gezsem mavi donlum var m'ola

Yeşil ördek yayllyyor çimende

Mehdi günü doğar âhır zamanda

Kürt'te Hindistan'da Çin'de Yemen'de

Aceb gezsem mavi donlum var m'ola

Mecliste içerler demi kanyadan

Güzel seven murad alır dünyadan

Kayseri'den Karaman'dan Konya'dan

Aceb gezsem mavi donlum var m'ola

Hacı Bektaş Velî şeyhlerin pîri

Konya'da yoklayın Molla Hünkâr't

Içel'den Antep'ten Gürün'den beri

Aceb gezsem mavi donlum var m'ola 


\section{Mardin'den de Karac'Oğlan Mardin'den}

Çeken bilir ayrllı̆̆ın derdinden

Koçhisar'dan Hasan Dağ'ın ardından

Aceb gezsem mavi donlum var m'ola (Sakaoğlu, 2004: 386).

Karacaoğlan bir ara Mardin'de bir ara Erzurum'da görülür. Şam'da Mısır'da, Aydın, Tokat, Ankara; Konya, Diyarbakır'da gönül eğlendirir. Karacaoğlan, “Adı sanı bilinmedik ellere gitmeyince gönül yardan ayrılmaz." diyerek adı sanı bilinmedik ülkelere, Avrupa illerine kadar uzanır. Sevdiği yâr için diyar diyar dolaşır. Demir çarık, demir asa bütün Anadolu'yu gezer. Kâh gerçek kâh gönül gözüyle illerde ala gözlüsünü arar (Makal, 1977: 12). Karacaoğlan'ın söz konusu şiirinde çaresiz ve umutsuz olduğu hissedilmektedir. Çünkü gönlünün sahibinden ayrılan âşık, bu acıyla kendini bilmediği diyarlara atmış yani göç etmiştir. $\mathrm{O}$, aşk derdinin acısının geçmeyeceğini bildiği için kalbindeki bu acıyla göç etmeyi yeğlemiştir. Güzeli, Niğde'nin Bor ilçesinde aramaya başlamış, Tokat'tan Toroslar'a indikten sonra Elbeğli üzerinden Diyarbakır'a geçtiğini şiirinde dile getirmiştir. Şairin bu hadsiz aşkı, onu Mısır'a ve hatta Çin'e kadar götürür. Sevgilinin ardından onu Konya, Karaman, Antep, Mardin gibi Anadolu'nun farklı noktalarında arasa da sevdiğini bulamaz. Ama Karacaoğlan bu yorgunluk ve arayıştan da bir an bile olsa bıkıp usanmaz. Çünkü her âşık gibi o da sevgili yolunda çekilen çilenin nefsi olgunlaştıracağını iyi bilir. Şair, içindeki ayrılık acısını söndürecek derde deva bulamadığı için diyar diyar gezer, kendini yollara vurur. Karacaoğlan'ın şiirinden hareketle aşkının göçüp gittiği yerler gibi uçsuz ve bucaksız olduğu anlaşılmaktadır.

\section{Akça klzlar göç eyledi yurdundan}

Koç yiğitler deli oldu derdinden

Gün ögle sonu da belin ardından

Saydım altı güzel indi pınara (Sakaoğlu, 2004: 397).

Mehmet Yardımcı (2014: 241), sevgilinin boyu, yüzünün güzelliği, gözlerinin rengi, göğüslerinin biçiminin somut ilişkilerle başlayan ve sonunda ulaşılacağı düşünülen birleşmenin ön uyarıcıları olduğunu belirtir.

Şairin bu dörtlügüünde, altı tane güzel akça kızın tıpkı kendisi gibi yurdundan göçüp pınar başına indiği görülmektedir. Zira pınar başı, geçmiş zamanlarda ve hatta az da olsa günümüzde de kızların salınıp kendini gösterdikleri bir mekândır. Sosyalleşme açısından son derece önemli bir yer olan pınar başı, Karacaoğlan'ın şiirlerinde kendisine yer bulmuştur. Karacaoğlan, pınar başındaki göçmen olan altı akça kızın güzelliğinden koç yiğitlerin del olduğunu belirtir. Çünkü âşık, sevgilisini gördüğü andan itibaren aklını yitirir ve delirir. Bu güzellik karşısında da koç yiğgitler tıpkı Mecnun gibi aklını yitirip deli olurlar.

Yaz olur dağlara ulu yol olur

Aşk olsun silasina da gidene

Bakın bahçadaki selvi fidana

All sunam kalk gidelim yaylaya (Sakaoğlu, 2004: 399).

Göçmenler yazın yaylaya çıkarlar, kışın ovaya inerler. Günümüz insanı için de çok önemli bir yeri olan yaylak ve kışlak göçmenler için çok önemlidir. Dörtlükte şair, yaz geldiğinde havaların isınmasıyla birlikte serinlemek ve rahat bir nefes almak yani yaylamak için yaylaya doğru olan göçleri anlatır. Göçülen bu yerlerde "bahçedeki selvi fidana" benzettiği güzelleri görenlerin o kadar etkilenip kendinden geçtiklerini ve sılasını dâhi unuttuklarını ifade eder. Dolayısıyla o da rahat bir nefes almak için sevdiğiyle beraber "tebdil-i mekân" eyleyip yaylaya gitme niyetini dile getirir. 


\section{Iraktır yolların dolandım geldim}

Tatlıdır dillerin eğlendim kaldım

Babalın boynuma işte ben öldüm

Mezarım göğsüne kaz kerem öyle (Sakaoğlu, 2004: 408).

Ozan, ilgili dörtlükte sılasından, yani çok uzak yollardan bir güzelin uğruna geldiğini söyler. Gurbette gördüğü bu can alıcı güzelin dili, tatlı olduğu için gönlü hoş olan Karacaoğlan, burada eğlenir kalır. Zaman öyle bir geçer ki sılasını bile anmaz ve istemez olur. Çünkü güzel, aşığın gönlünü gurbette hoş eylemeye başlamıştır bir kere. Dolayısıyla gönlü eğlenen âşık için yeni sıla, sevgilinin bizzat yanıdır. Artık aşk acısıyla sevgiliden başka gözü hiçbir şey görmeyen Karacaoğlan, sevdiğiyle bir bütün olabilmek için ona gelecek tüm kaza ve belaların kendi üzerine gelmesini ve sevgilisinden bir kerem göstererek naçiz vücudunun göğsünde olmasını ister.

Kalktı deli gönül sürdü yürüdü

Gel oldu gidelim bizim ellere

Gözyaşlarım yeryüzünü bürüdü

Sel oldu gidelim bizim ellere

Kavim kardaş bir araya derildi

Güzel dilber oldum deyi yerindi

Kitaba baktım ki yollar göründü

Gel oldu gidelim bizim ellere (Sakaoğlu, 2004: 412).

Anadolu insanının içine işlemiştir gurbet acıları. Hemen her ev, en az bir erini gurbete yollamıştır. Karacaoğlan Türk'ün gurbet duygusunu, gurbetteki düşüncelerini mısralarında kuvvetle dile getirmiştir. Sevenlerin, birbirlerine demek istediklerini Karacaoğlan'da buldukları gibi, gurbet ilde bulunanlar da gurbet acıları içinde, sıla özlemleri içinde kıvranırken Karacaoğlan'a sarılmışlardır (Makal, 1977: 86). Karacaoğlan bu şiirinde ise bitmek bilmeyen memleket hasretini dile getirir. Sılasına gitmek için bir bahane bir neden bulmak ister. Ne yapıp edip gönlünün deli olmasını bahane ederek sılaya dönme isteğini dile getirir. Şair, memleket hasretinden o kadar çok ağlar ki gözyaşları sel olur ve çağlar. Özellikle aşkından yüz bulamayan âşık, sılada olan kavim kardaşın da bir araya geldiğini duyunca bunu kendisi için bir sebep olarak görür ve sıla için yola koyulmak ister.

Dağlar geçit verin konup geçeyim

Bir daha bu ele gelmeyesiye

Bağrıma hançerin salan elleri

Bir daha dönüp de görmeyesiye

Eller göçtü geçti bense göçmedim

Yâr elinden dolu bâde içmedim

Kı bana gücenmiş kusur işledim

Hesabın us yetip vermeyesiye (Sakaoğlu, 2004: 414).

M. Necat Karaer (t.y.: 86), bir yiğidin gurbet gezmeyince, insan değerini, yurdunun, dostlarının değerini bilemeyeceğini ifade eder.

İlk dörtlükte şair dağlara seslenir. Dağlar şaire yol olunca, şair bir daha dönmemek üzere göçmek ister. Sebebini ise ikinci dörtlükte söyler. Şair, sevdiğine kusur eylemiş, sevdiğinin kalbini kırmıştır. Geriye dönüp sevdiğinin yüzüne bakınca hesap veremeyecek hâle gelmiştir. Bu yüzden gurbet ellerini tek tek dolaşacaktır. "Eller göçtü bense göçmedim" dizesinde her yiğidin gurbet gezip göç etmesi gerektiğini dile getirir. 
Oğlan sen kendini ileri atma

Gizli sırların yadlara satma

Bilip bilmediğin her yere gitme

Yabancı deremez güllerimizi (Sakaoğlu, 2004: 433).

Güzel, Karacaoğlan'a, gizli sırlarını yabancılara anlatmaması gerektiğini ve bilip bilmediği yani önüne gelen her yere rastgele göç edilemeyeceği hususunda öğüt verir. Dörtlükte ellerin diyarına göç etmekten sakınma, gurbetin sılaya benzemeyeceği dile getirilmiştir. Karacaoğlan'ın gizli sırları yâre söylediği gizli sözleridir.

Mehmet Yardımc1 (2014: 257), Karacaoğlan'ın “Yare gizli sözlerim var, Diyemiyom ele karşı" semaisinde aşığın sevgilisine söyleyeceği gizli sözleri olduğunu; fakat bunu bir türlü yabanc1lar önünde söyleyemediğini ifade eder.

Giden gelmez giden gelmez

Aşinasin ă̆latan gülmez

Geyim ile meydan olmaz.

Vur kantara tart yiğidi (Sakaoğlu, 2004: 438)

Ölümden sonra geri dönüşün olmayacağı aşikârdır. Sevdiklerini, tanıdıklarını ağlatanın da öteki dünyada yüzü gülmez. Bu dünyada iyi giyinmekle insanın dürüstlüğü ölçülmez. İnsanoğlu bu dünyada yaptıkları ile öteki dünyada hesap verecektir. Yiğit olanın kantara ihtiyacı yoktur. Yiğitlik insanın dürüstlüğü ile ölçülür.

"Bilmez ki giden sevgililer dönmeyecekler.

Birçok gidenin her biri memnun ki yerinden,

Birçok seneler geçti; dönen yok seferinden."

Yahya Kemal Beyatlı ölümü, ilgili dizelerde kişinin fâni dünyayla ilişkisini kestiği acı bir gerçek olarak tanımlar. Karacaoğlan'ın "giden gelmez giden gelmez" dizeleriyle mana bakımından bir örtüşme görülmektedir. Bu dizelerde Beyatlı'nın Karacaoğlan'dan esinlendiğini yani etkilendiği hissedilmektedir.

Hasta oldum odalarda yatarım

Beylere göçecek zaman da geldi

Tutuştu bir uçtan yandı evleri

Bürüdü dağlarl duman da geldi (Sakaoğlu, 2004: 439).

Şiirde, göç mecazi bir bağlamda ifade edilmiştir. Dünya değiştirme veya bir yolun sonu olarak -ki her son bir başlangıçtır- görülen ölüm, halk şiirine özgü benzetmelerle betimlenmiştir. Şiirde, ölüm olarak algılanan göçün; genç-yaşlı, zengin-fakir, 1rgat-bey ayrımı yapmadan herkesin başında olabileceğine dair vurgu yapılmıştır.

Dost elinden bâde içtim

Gurbetlere andan düştüm

Gurbet elde çok eğleştim

Nazlı yârim ağlar şimdi (Sakaoğlu, 2004: 443).

Göç, âşık olmanın gerekliliğidir. Çünkü aşk, gurbette daha da bir derinleşir ve anlam kazanır. Şair gurbet elde gezer, dolaşır; fakat o'nun bir bekleyeni vardır. Sevdiği kız özleminden yollarını gözler. Karacaoğlan ile aynı yörenin insanı olan Musa Eroğlu da Karacaoğlan'dan feyz alarak yârine;

"Telli turnam selam götür

Sevgilimin diyarına

Üzülmesin ağlamasin

Belki gelirim yarına cananıma" diye seslenerek söz konusu etkiyi en derin noktasına kadar hissettirmiştir. 
Biz de düştük bir güzelin ardına

Güzel göçmüş biz konalım yurduna

Ylkılası karlı dă̆ın ardına

Çekip gider bir gözleri sürmeli (Sakaoğlu, 2004: 444).

Bir Türkmen gelinidir Karacaoğlan'ın sevdiği, Ayşe'dir, Elif'tir, Hörü, Zeynep, Dürrü'dür. Hayalinde değildir Karacaoğlan'ın sevdiği; güneş gibi, ay gibi ayan beyandır. Saçları sırmalıdır, boyu uzun; gözleri kudretten sürmelidir. Kuğu süzüşlüdür. Karacaoğlan'ın sevdiği onun için, turnadır. Gül fidanıdır. Karacaoğlan'ın sevdiği, elinde güller vardır, nergisler, menekşeler vardır elinde; başına sümbüller takmıştır. Ak bedenleriyle kuğulara benzer Karacaoğlan'ın güzelleri, başlarındaki yeşil örtülere, yeşil başlı ördeklere; bakışlarıyla ceylana, kaçışıyla geyiğe benzer. Ayaktaki nalın, nakışlıdır. Kız, yavru şahin bakışlıdır. Dudaklarından bal akar. Karacaoğlan'ın sevdiğinin ağzı, oğul balı kadar, frenk şekeri kadar tatlıdır. Yayla kızlarının ince bellerinde, marifetli ellerinde dokunan canlı çiçek motifli kumaşlarda misk gibi kokan yeni gelin kokusudur. Karacaoğlan'ın aşkı, ak gerdanda dudağın dokunduğu ben'dir, binlerce ben'dir (Makal, 1977: 53). Gözleri sürmeli olan güzel, karlı dağların arkasına göçer. Dolayısıyla aşığa yine yol, yine gurbet yine hasret düşer. Karacaoğlan, güzel her nereye gider ise bir kuş misali onu takip etmektedir. Çünkü aşığın yeri sevgilisinin yanıdır. Yani aşığın bir doğduğu yer olan bir de sevgilisinin yanı -ki bu asıl sıladır- olan sılası vardır. Şair sevdası için yurdundan bile göç etmeyi göze alır. Karacaoğlan, sılasından asıl sılaya -gurbet de olsa- göç etmeyi bir an bile düşünmez.

Yaz baharın suyu gibi bulandım

Heybe taktım kapı kapı dilendim

Yedi iklim dört köşeyi dolandım

Vallahi görmedim eşin sürmeli (Sakaoğlu, 2004: 445).

İlgili dörtlükte, güzelin dünyada ondan başka eşi benzeri olmayacağı anlatılmak istenmektedir. Çünkü halk şiirinde bir gelenek olarak güzel, eşi menendi bulunmayan selvi boylu, inci dişli, kömür gözlü bir yârdır. Şairin gönlü gözü ondan başkasını görmez. Daha doğrusu bu göz ve gönül, o'ndan başka her şeye kör ve kapalıdır. Şair sevdiği için tüm dünyayı dolaşır, dolaşır ama; yine de onun gibisini bulamaz.

Dadaloğlu yedi iklim dört köşeyi dolaşmış lakin dünyada adaleti ve doğruluğu bulamamıştır. Karacaoğlan da tıpkı Dadaloğlu gibi yedi iklim, dört köşeyi dolaşmış; ancak güzelinden başka bir güzel; aşkından daha yüce bir aşk bulamamıştır. Karacaoğlan'ın güzeli de aşkının sonudur, ondan öte kalbine bir yâr konmaz. Artık Karacaoğlan'ın evveli ve ahiri o aşk olmuştur.

\section{Başına sokulmuş gülü lâlesi \\ Yaktı beni kaşlarının karası \\ El göçüp kendi burada kalası \\ Dağlarında melil kalan güçücek (Sakaoğlu, 2004: 470).}

Sevgilinin kaşlarının karası bir kor misali aşığın gönlünü yakar. Şair yabancıların göçüp gitmesini, dağlarda süzülen taze bir çiçek misali sadece o'nun yani sevgilinin kalmasını ister. Burada da dolaylı yoldan bir göç sezilmektedir. Diğer göçlerin aksine şair, burada diğer kişilerin göç etmesini isteyerek sevgilisiyle başbaşa kalıp ele güne karşı yârine söyleyemediklerini söylemek yani derdini dökmek için uygun ortam hazırlamak gayretindedir.

Eller göçün çekti bense göçmedim

Yâr elinden dolu bâde içmedim 


\section{Bilmem hata ettim kusur işledim}

Cahilim kıymatın bilmedim felek (Sakaoğlu, 2004: 471).

İlgili dörtlükte yar elinden dolu içemeyen âşık, ellerin göç etmesine rağmen göç edemediğini dile getirir. Oysaki sevdiğinin elinden bir kadeh dolusu içmesi, göçe meyil verecektir. Şair göç etmeyişini cahilliğine vurur, bu yüzden feleğe dert yanar.

Seyyah oldum gezdim gurbet elleri

Kâr etti bağrima yeter ayrilı

Söyleyeyim başa gelen hâlları

Ölümden çok çektim beter ayrılık

Şu aşkın ataşı sönmüyor serde

Ah çeker ă̆larım gezdiğim yerde

Ben burda kalmışım dost gurbet elde

Beni elden ele atar ayrılık (Sakaoğlu, 2004: 473).

Karacaoğlan, gurbet diyarlarına seyyah olup göç eder. Göç; sevgiliden, yurttan, dosttan ayrılma nedenidir. Ayrılık insanın kalbine dokunur, insanı incitir. Ayrılık ölüm acısından bile daha ağırdır çoğu zaman. Bir gelenek bağlamında Allah'ın emri olarak bilinen ölüm karşısında sonsuz bir kabullenme varken; gurbet yani ayrılık, çok acı bir mefhum olarak şiirlerde kendine yer bulmuştur. Ölüm ve ayrılık acısında ayrılık, daha ağır basmıştır. Ayrılık dostu dostundan ayırır, dost bilmez ellere yâr eder. Şair bu dörtlükte göç edişin arkasında bıraktıklarını hüzünlü bir dille ifade etmiştir.

Gurbette ömrüm geçecek

Bir daracı yerim de yok

Oturup derdim dökecek

Bir münâsib yârim de yok (Sakaoğlu, 2004: 473).

Ozan, yabancı ellere göç eder; gurbete ömrünü verir. Kaçınılmaz bir son olan gurbette ne yatacak yer ne de derdine derman olacak bir eş bulacaktır. Çünkü Karacaoğlan'ın yeri yurdu yoktur ve gönlü, sevgiliden dolayı kimsesizdir. Bu derdini de dökecek biri olmadığından içinde bulunduğu çaresiz durumu dile getirmiştir.

Irganayım ala beşik içinde

Görüneyim güzellerin göçünde

Kamalaklı kara ardıç içinde

Kırmızı önlüklü yâr ister gönül (Sakaoğlu, 2004: 482).

Şair kendisini bir ağacın içinde üşümüş, yalnız kalmış bir kekliğe benzetmektedir. Güzellerin göçünde görünmek istemesi de bu yüzdendir. Çünkü Karacaoğlan, gönlüne göre kırmızı önlüklü bir yâr bulmak ister.

Renk ve sayı simgeciliği konusunda araştırmalar Bayram Durbilmez'in tespitlerine göre, kırmızının "heyecan, cesaret, mücadele, koruyuculuk, tehlike, yenilenme, hayatta kalma, hayat verme, kudret, hâkimiyet/ savaş, ergenlik, kağanlık, sonsuzluk, mutluluk, murat, güneş/ ışık anlamları vardır." (Durbilmez, 2017: 68). Kırmızı rengi divan şiirinde de sıkça kullanılır. Hükümdar otağı, kanın ve bayrağın rengi kırmızıdır. Şarabın sıcaklığı kırmızı ile hissettirilmiştir. Kırmızı, güzele en çok yakışan renktir. Sevgilinin dudakları ve yanakları kırmızıdır. Sevgilinin kıyafetleri kırmızı renkli olduğu için aşığın dikkatini çeker. Yunus Emre, gelinliğe kırmızı rengini yakıştırır. Karacaoğlan ise sevgilinin önlüğünü kırmızı renkli olmasını ister. Çünkü kırmızı rengi güzeli cazibeli ve alımlı kılar. Kırmızı, güzeli seçmek için bir sebeptir. 
Döndüm dolaştım ben gurbet elleri

Dünyaya çıkmağa yol bulamadım

Bahçalarda gördüm birçok gülleri

Sevdiğime benzer gül bulamadım (Sakaoğlu, 2004: 483-484).

Karacaoğlan, gurbet ellere göç etmeyi ahirete göç etmeye benzetmektedir. Gurbet eller, ölüm kadar uzak ve bir o kadar da yakındadır. Gurbete düşen yurdunu özler; fakat geri dönüşü zor olan bir yola girmiştir artık. Gurbet ellerde çok gezip ve birçok güzel gören âşık, yine de sevdiğinin eşşiz güzelliğini hiçbir güzel ile kıyas edememektedir.

Eller yaylasina göçtüğ̈̈ zaman

Bülbül gülden ben yârimden ayrıldım

Dilim söyler amma gözlerim ăglar

Bülbül gülden ben yârimden ayrıldım (Sakaoğlu, 2004: 486).

Söz konusu dörtlükte, yârdan ayrı kalma eylemi, bülbülün gülden ayrılmasına ve ellerin yaylaya göçtüğü zamana bağlanmıştır. Gül, bülbülün kokladığı ve misafir olup ruhunu doyurduğu bir çiçektir. Âşı ğın yârinin kokusu gül gibi kokar, âşı̆̆ın ruhunu donatır ve onu, cezbe hâline sokarak kendisinden geçirir. Aşk acısı çeken -ki bu durumdan da son derece hoşnut olan- âşık, tıpkı bülbül gibi kendisi de yârinden ayrıldığı için kanlı gözyaşları akitir.

Gittim gurbet ele geri gelinmez.

Kim ölüp de kim kaldı ğ bilinmez

Ölsem gurbet elde gözüm yumulmaz

Anam atam bir ağlarım yok benim (Sakaoğlu, 2004: 499).

Şiirde ozanın geri dönüşü olmayan gurbet ele düştügüü görülmektedir. Gurbet, uzak bir yer ve yoldur. Oradan haber de gelmez. Halk şiirinde âşılar, gurbetteki sevdiklerine kimi zaman kuşlar kimi zaman rüzgâr kimi zaman da mektup ile selam gönderir. Ama o, bu uzak diyarlardan hiçbir zaman haber alamaz. Gurbette kimi kimsesi olmayan olamayan her insanda olduğu gibi âşığın da en büyük korkusu yalnız ölmektir. Çünkü halk kültüründe bir alkış olan "Allah kimsenin ölüsünü yalnız bırakmasın." inancı, halk şiirinde ve Karacaoğlan'da kendisini derinden hissettirmektedir. Çünkü ölen bir insan için aile, ahbap, eş-dost tarafından yapılan son görev çok önemlidir. Gurbette olan âşık, göç ettiği gurbette ölüsünün kimsesiz kalmasının korku ve endişesi içerisindedir.

Karac'oğlan der ki konanlar göçmez

Bu ayrılık bizlen arasın açmaz.

Bir kötü gönlüm var güzelden geçmez

Ne güzele doymaz gözüm var benim (Sakaoğlu, 2004: 500).

Konup da göçülemeyen tek yer ölümdür. Ölümden gayrı dönülmeyecek hiçbir yol yoktur. Ölüm, reel bağlamda âşığın sevdiğinden ayrılma sebebidir. Fakat şair, ölümün dahi sevdiği ile arasına giremeyeceğini ve ölümün aslında bir ayrılık sebebi olamayacağını dile getirir. Şair, yârinden ayrı kalsa da gönül kapısının kapanmayacağını, gözleri birçok güzel görse de gönlünün sahibinin o eşi menendi bulunmayan güzelde olduğunu ifade eder.

Hey ăgalar bir onulmaz derdim var

Olur olmaz yere açamıyorum

Bir yâr için çıtım gurbet ellere

Terk edip sılaya geçemiyorum (Sakaoğlu, 2004: 510).

Karacaoğlan, derde derman olacak kişilere seslenerek dermanı olmayan bir derdinin olduğunu dile getirir. Ozan yâr için gurbet ellere çıkmıştır. Bu gurbet kimi zaman yâri aramak kimi zaman da iç sıkıntılardan kurtulmak için yapılan "tebdil-i mekân"dır. Şiirde, 
yâri aramak için gurbete çıkan âşığın, yeni yurdunu görünce sılasından vazgeçtiği ve sılaya dönmek istemediği anlaşılmaktadır. Sevdiğini almadan yurduna dönmek istemez. Âşık, sevdiği ile yurdu arasında kalmış, çaresiz derde düşmüştür. $\mathrm{Bu}$ yüzden hâlden anlamaz kişilere derdini dökememektedir.

Erciyes 'te yă̆an karlar

Seher ile göçen eller

Zamânede Elif derler

Bir güçücek gelin gördüm (Sakaoğlu, 2004: 513).

Ozan, Erciyes'te kar yağmaya başladığında artık yaylada durulacak zamanın kalmadığını ve bu yüzden seher vaktinde göçün başladığını anlatır. Yine bu göç eyleminin birinde Elif adında, zarif bir gelin gördüğünü dile getirir. Genelde yaylada, dağ başında ve bilhassa pınar başında görülen güzeller, bu kez göç ederken görülmüştür.

Karac'oğlan der ki kondum göçülmez

Acıdır ecel şerbeti içilmez

$\ddot{U} c ̧$ derdim var birbirinden seçilmez

Bir ayrılık bir yoksulluk bir ölüm (Sakaoğlu, 2004: 514).

Karacaoğlan, burada bizzat kendisinden bahsetmektedir. Ecel şerbetinin yani ölümün acı olduğunu belirtir; ancak bunun kaçınılmaz bir son olduğunu da çok iyi bilir. Şiirde Karacaoğlan'ın hayatında “ayrılık, yoksulluk ve ölüm” gibi biri, diğerini aratmayacak üç derdinin var olduğu anlaşılmaktadır.

Niçin böyle melil melil gezersin

Şâd u hurrem olup gül kömür gözlüm

Arzu eder gönlümün gurbet elleri

İște gidiyorum kal kömür gözlüm (Sakaoğlu, 2004: 515).

Ozan burada kendi gönlüne seslenir. Gönlünün avare olmuş bir biçimde melil melil gezmesinin nedenini bilmesine rağmen bilmez gibi davranır. Daha önce de belirtildiği gibi göç, faklı nedenlerle yapılır. Buradaki göç, sevdiğini memnun etmek adına yapılan bir eylemdir. Çoğu zaman sevgilinin ardından sıla terk edilerek yapılan göç olgusu, burada farklı bir yapı arz etmektedir. Şiirde göç, "bağıra taş basıp” sevgiliden uzakta onun aşkı ile yanıp tutuşma amacıyla yapılır. Göç edilen bu yerde kimi kimsesi olmayan âşığın tek duası, sevgilisinin mutlu olması ve hayatına rahat bir biçimde devam etmesidir.

Yaz gelip de beş'ayları doğunca

Akar boz bulanı selinden sakın

Gurbet elde kimse bilmez ahvalın

Sen dur vatanında elinden sakın (Sakaoğlu, 2004: 534).

Beş aylar tabiri, mısralarda anlamı güçlendirmektedir. Karaer, (t.y: 77) Türkmen takviminde mevsimlerin adları bildiğimizden farklı olduğunu ifade eder. Yaz için "yay", bahar karşılığı için de " $y a z$ " terimi kullanılmaktadır. Yine bu takvime göre yediye ayları, beşe ayları, üçe ayları ve bire ayları vardır. Karaer'e göre, Beş ayları "Nisan ve Mayıs" aylarına tekabül eder. Karacaoğlan'ın gurbet elde başına bir iş geldiğinde durumunu, hâlini, hatırını soracak kimsesi yoktur. Şair gurbet elde, etrafındaki kişilerin ahvalini bilmediğinden yakınır. Çünkü gurbette, kişinin etrafında birileri olsa da yalnızdır. Gurbetçilere her zaman misafir gözüyle bakıldığı için onların derdi ve ahvalleriyle hemhâl olunmaz. Bu duruma maruz kalan âşık, içsel durumunu dile getirirken mümkün mertebe sıladan göç edilmemesini tavsiye eder.

Bir yiğit slladan gitmeli olsa

Acısı yüreğinden gitmez silanın 


\section{Ĕ̆lenip gurbette mekân bağlasa}

Hayali gözünden gitmez sılanın (Sakaoğlu, 2004: 536).

Gurbette olan gurbetçinin hâliyet-i ruhaniyetinde doğup büyüdüğü, özlediği en önemli yer, sıladır. Sıla, bir insanın çocukluğudur, geçmişidir, acısıdır, sevincidir, toprağıdır, babasıdır, dostudur, yâridir. Yani sıla, onun geçmişinde iz bırakan her şeydir, vazgeçemediği tek şeydir vesselam. Karacaoğlan, gurbet ellere göçse de sıla acısının yüreğinden bir an bile olsun çıkmadığını, her an yüreğinin sıla hasreti ile yandığını ve gözlerinde sıla hayali ile yaşamaya devam edeceğini vurgular.

Benim ahdim ak geline kalmaya

Çeke çeke bir derd ile ölmeye

Gurbet elden şu kocasi gelmeye

Daha derdim az diyesin ak gelin (Sakaoğlu, 2004: 548).

Söz konusu dörtlükte bir ahd, yani sözün verildiği görülmektedir. Onun bu ahdi, ak geline kalmak için verilmiştir. Ama ne çare ki ak gelin, evli olan bir kişidir. Bu durumu bir dert olarak gören âşığın duası, sevdiğinin bu dertten kurtulmasına yöneliktir. Aslında bu duanın alt yapısında bir de beddua vardır. Âşık, yüreğinin yangını ile sevgilinin eşi olan çirkin adamın ölmesini diler. Böylelikle sevgilinin kendisine kalacağ 1 ve bir dertten kurtulacağına inanır. Karacaoğlan söz konusu hâliyet-i ruhaniyetini farklı bir şiirinde ise;

"Şu dağların yükseğine erseler

Lale sümbül mor menevşe derseler

Bir güzeli bir çirkine verseler

Güzel ăglar çirkin güler bir zaman

Yükseğinde olur şahin yuvası

Endim engine Avşar ovası

Kabul olur güzellerin duası

Haktan sevdiğini diler bir zaman

Vara vara vardık Alma Deresi

Uzak kaldı nazlı yârin arası

Artıyor dinmiyor gönül yarası

Mevla'm dermanını salar bir zaman" sözleri ile dile getirmiştir.

Güzelsiz yaylaya konup göçülmez

Kelle kesmek ile kanlar saçılmaz (Sakaoğlu, 2004: 555).

Karacaoğlan'a ait olan şiirin bu beyitinde ise göçme eyleminin nedeni sevgiliye bağlanmıştır. $\mathrm{O}$, güzelin yani sevgilinin olamadığ 1 yerlere hiçbir şekilde konup göçmek istemez. Çünkü sevgilinin olmadığı yer, âşık için bir anlam ifade etmez.

Kömür gözlüm ben bu yerden gidersem

Var bana nisbetle gez uğrun uğrun

Rakib değilim ki aranı bozam

Yadlara düğmeni çöz uğrun uğrun (Sakaoğlu, 2004: 564).

Ozan bu dörtlükte sevgiliye sitem etmektedir. S1ladan göçüp gittiğinde sevgilinin kendisine nispet yaparcasına gezmesini ister. Bu sitem, daha da ileri götürülerek kendisinin rakip olmadığını ve yad ellere yani yabancılara da gitmek isterse gidebileceğini söyler. Aslında âşık bunları söyleyen ya da söyleyebilecek bir kişi değildir. Ama aşk acısı onu delirtmiştir bir kere. "Aşk ağlatır dert söyletir." mefhumu, burada kendisini içli bir biçimde hissettirmektedir.

Durnam göç eylemiş düzmüş bir gater

Şahin girmiş arasına çı̆̆rışır öter 
Müşteri olana telini satar

Yavrı şahin heybetinden toz vurup gider (Sakaoğlu, 2004: 589).

Turnalar Anadolu'nun hemen hemen her mecrasında bereketin, mutluluğun, refahın habercisi olarak görülür. Vefanın, sadakatin, saflığın, sabrın, özgürlüğün ve onurun simgesi olarak da algılanılmaktadır. Türkülerde sılaya selam ve haber götüren bir dost olarak anılan turnalar, ilgili dörtlükte olduğu gibi göç eylemini gerçekleştirmiştir. İlaveten buradaki söz konusu turna, aslında sevgilinin de bizzat kendisidir. Sevgilinin sıla gibi bir endişesi yoktur. Onun göç edip gittiği her yer âşıkların en önemli durağı yanı asıl sılasıdır. Şiirde göç eden sevgilinin, etrafındaki kişiler yani rakipler, şahin olarak tasavvur edilmiştir. Turna, âşığı haricindeki her şey ile alakadar olur. Önemsemediği tek şey peşinden perişan bir biçimde göç eden âşığıdır. O sevgili öyle bir güzeldir ki etrafındaki yeni yetme güzeller bile ona hayrandir.

Ben de çıkayım da dağlar başına

Dayanamam toprağına taşına

Beni kınayanın gelsin başına

Bana sıla da bir gurbet el de bir (Sakaoğlu, 2004: 603).

Karacaoğlan, aşkının hasret ve özleminden dolayı içine kapanmış ve yalnızlaşmıştır. Dağlar başını kendine yer eyleyen âşığın daha önce de belirtildiği gibi sıla anlayışı farklıdır. Onun için asıl sıla, sevgilinin yanı olması hasebiyle âşık için gurbet de sıla da birdir.

Gel gönül gurbete gitme

Ya gelinir ya gelinmez

Her güzele meyil verme

Ya sevilir ya sevilmez (Sakaoğlu, 2004: 649).

Şiirde Karacaoğlan, laf dinlemeyen söz anlamayan deli gönlüne seslenir. Çünkü göç eden her ne kadar beden gibi görülse de temel yapıda ruhun bizzat kendisidir. Acıyı, özlemi, hasreti çeken beden değil; ruhtur. Çalışmanın sonunda verilen bu dörtlükte, gönül maceralarının en inceliklerine kadar hissettiğimiz Karacaoğlan, hayattan alması gereken her türlü dersi almıştır. $O$, her güzele gönül verilmeyeceğinin bilincine ve olgunluğuna varmıştır. Ömrü gurbette, geçen veya geçecek olan âşıklara bir tavsiyede bulunarak her güzele gönül vermenin tehlikeli olduğu, gurbete gidenin geri dönmesinin de müphem olduğu için göç ve sevme eyleminin acılarla ve hasretle sonuçlanacağını ifade etmiştir.

\section{SONUÇ}

Göç, aşağı yukarı tüm toplumları etkileyen insanlık tarihiyle özdeş; insanlık tarihinin tüm dönemlerinde var olan ve bugün de varlığını devam ettiren bir sosyal faaliyettir. Göç genel anlamda, insanların bir yerleşim biriminden bir diğerine yönelerek gerçekleştirdiği yer değiştirme eylemi olarak bilinmektedir. Tarihsel süreç içinde insanlar, ekonomik, sosyal, siyasi ve doğal nedenlerden ötürü farklı göç türlerini deneyimlemişlerdir. Farklı toplumsal, ekonomik ve siyasi koşullar sonucu biçimlenen göç hareketleri, aynı zamanda toplumların sosyo-kültürel, ekonomik ve mekânsal yapısını biçimlendiren önemli olgulardan biri olarak folklor, sosyoloji, antropoloji vb. literatürde de yerini alarak kendisini birçok alanda olduğu gibi edebî ürünlerde de göstermiştir. Söz konusu olgu, Karacaoğlan'dan önce, Karacaoğlan devri ve günümüze kadar halk şiirinde yoğun bir biçimde yer alarak karşımıza çıkmıştır.

17.yüzyıl Âşık Edebiyatı'nın önemli temsilcilerinden biri olan Karacaoğlan, konar göçer yaşam tarzının üyesi olan bir kişiliktir. Sosyo-kültürel bağlamda göç olgusuna maruz kalan âşık, bu durumu icra ettiği eserlerine sirayet ettirmiştir. Anadolu'nun dört farklı coğrafyasına ve hatta Suriye; Hama, Hums ve Halep'e kadar giden Karacaoğlan, gezip 
gördüğü yerlerin tecrübe ve görgülerine de şiirlerinde yer vermiştir. Onun şiirlerinde göç, kimi zaman bir sebep kimi zaman ise bir sonuçtur. Halk şiirinin büyük bir bölümünde olduğu gibi Karacaoğlan'ın şiirlerinde de "sıla ve gurbet" kavramları her ne kadar tezat gibi görünse de aslında birbirini tamamlayan yapılardır. Çünkü halk şiirinde âşığın iki ana vatanı vardır. Bunlardan birisi doğum yeri olan yer iken diğeri de sevgilinin yanı olan vatandır. Karacaoğlan'ın şiirlerinde göç, çoğu zaman sevgilinin ardına yapılırken kimi zaman da sevgilinin isteği veya yaptıklarından dolayı farklı diyarlara doğru yapıldığı görülmektedir. Kısacası, "Göç" Türk halkının vazgeçilmezlerinden biridir. Göç, insanın alıştığı yerlerden uzaklarda bir umut arayışıdır. Daha kolay ve rahata kavuşma uğruna sevdiklerini terk etmesidir. Göçün neden olduğu gurbet, gariplik duygusu ve yalnızlık, halk şiirimizin temel bir konusu olarak; halk şairlerimizin gönül tellerini titretmiş ve bir iç sızısı olarak onların şiirlerine sinmiş, hayatlarının olmazsa olmazı olmuştur.

\section{KAYNAKÇA}

ARI, Bülent (2006), “Karacaoğlan’ın Şiirlerinde Sevgilinin Giyim Kuşamı”, Türk Kültürü ve Hacı Bektaş Veli Dergisi, Sayı 13/38, Ankara, s. 93-107.

ARI, Bülent (2016), Bir Deste Karacaoğlan-Karacaoğlan Makaleleri, Color Ofset Matbaacilık, İskenderun.

ÇELİK, Ali (2008), Türk Halk Şiiri Antolojisi, Timaş Yayınları, İstanbul

DURAL, A. Baran- ZEYREKLİ, Sedef (2006), "Göç Sorunu ve Gecekondulu Nüfusun İktidara Yürüyüşü”, Çağdaş Yerel Yönetimler c. 15/4: 5-14. Ankara, TODAİE.

DURBİLMEZ, Bayram (2007), "Renk Adına Bağlı Mahlaslar ve Karacaoğlan Mahlaslı Halk Şairleri”, Doğumunun 400. Yılında Uluslararası Karacaoğlan Sempozyumu, (Hzl. Kudret Ünal), 30-44, Tarsus, Eylül 2007.

DURBİLMEZ, Bayram (2017), Türk Dünyası Kültürü-1, Ötüken Yayınları, İstanbul. ERGİN, Muharrem (1991), Orhun Abideleri, Boğaziçi Yayınları, İstanbul.

KARAER, Mustafa Necat (Tarihsiz), Karacaoğlan 1001 Temel Eser, Tercüman Gazetesi.

KAYGALAK, Sevilay (2001),Yeni Kentsel Yoksulluk, Göç ve Yoksulluğun Mekânsal Yoğunlaşması. Praksis (2), s. 124-172.

KELEŞ, Ruşen (1998), Kent bilim Terimleri Sözlüğü, İmge Kitabevi, Ankara.

KOCAMAN, Tuncer (2008), Türkiye'de İç Göçler ve Göç Edenlerin Nitelikleri, Başbakanlık Devlet Planlama Teşkilatı, Ankara.

MAKAL, Tahir Kutsi (1977), Karacaoğlan, Toker Yayınları, İstanbul.

ÖGEL, Bahaeddin (1998), Türk Kültür Tarihine Giriş I, Kültür Bakanlığı Yayınları, Ankara.

ÖZER, İnan (2004), Kentleşme, Kentlileşme ve Kentsel Değişme, Ekin Kitabevi, Bursa.

SAKAOĞLU, Saim (2004), Karaca Oğlan, Akçağ Yayınları, Ankara.

TDK (2011), Türkçe Sözlük, TDK Yay., Ankara.

YARDIMCI, Mehmet (2014), Yaşamları ve Sanatları ve Şiirlerinin Yorumlarıyla Âşıklarımız Halk Şiiri Tahlilleri, Kanyılmaz Matbaacılık, İzmir. 